\title{
INSURANCE CONDITIONS FOR ENVIRONMENTAL LIABILITY
}

\section{Eva Vávrová}

\section{Klíčová slova:}

pojistný trh, komerční pojišt'ovna, pojistný produkt, environmentální pojištění, pojistitelnost, pojištění odpovědnosti za škodu, řízení rizik

\section{Key words:}

insurance market, commercial insurance company, insurance product, environmental insurance, insurability, liability insurance, risk management

\begin{abstract}
Abstrakt
Směrnice o odpovědnosti za škodu na životním prostředí a její nápravě č. 2004/35/EC (Environmental Liability Directive) od dubna roku 2004 reguluje odpovědnost za škody na životním prostředí v Evropské unii. Byla doplněna dalším předpisem č. 2006/21/EC. Hlavním účelem legislativy bylo zabezpečit, aby původce škody uhradil veškeré náklady na odstranění následků (tzv. polluter-pays-principle). Když dojde ke škodě na životním prostředí, provozovatel musí provést opatření $\mathrm{k}$ rehabilitaci, náhradě a regeneraci poškozených přírodních zdrojů. Rozlišuje se primární náhrada, která vrací poškozené prrírodní zdroje do jejich původních podmínek, dále komplementární náhrada jakožto kompenzace $\mathrm{v}$ př́ípadě, že primární náhrada neposkytla dostatečné odškodnění, a konečně případná kompenzační náhrada - kompenzace dočasné ztráty prrírodních podmínek.

Stěžejním záměrem př́spěvku je rozbor specifických předpokladů pojistitelnosti rizik v případě environmentálního pojištění, to jest pojištění odpovědnosti za škodu na životním prostředí. Předkládaný vědecký příspěvek prezentuje poznatky získané při rozboru environmentálního pojištění jakožto konkrétního způsobu eliminace rizik v př́padě odpovědnosti za škodu na životním prostředí způsobenou činností provozovatele, jehož aktivita potenciálně ohrožuje životní prostředí a může zapř́íčinit i ekologickou újmu. V práci je rozebrán především přístup Evropské unie a legislativní požadavky stanovené výše uvedenou směrnicí, které jsou posouzeny s ohledem na dopad do podmínek České republiky. Rizika jsou posuzována se zřetelem na kritéria pojistitelnosti možných škod na životním prostředí. Je zdůrazněn význam risk managementu, v sofistikovanější podobě označovaného jako Enterprise Risk Management. Řízení rizik nabývá na významu právě v současnosti společně s důslednou kvantifikací zjevných, skrytých i potenciálních rizik.

V příspěvku jsou publikovány dílčí výsledky dosažené v rámci výzkumného záměru MSM 6215648904/výzkumný směr 02 s názvem „Hlavní tendence ve vývoji konkurenčního prostředí v podmínkách integračních a globalizačních procesů a adaptace podnikatelských subjektů na nové podmínky integrovaného trhu“, v návaznosti na cíle a metodiku řešení daného výzkumného záměru.
\end{abstract}

\begin{abstract}
Since 2004, the Environmental Liability Directive No. 2004/35/EC is the basic document which has governed liability for damage to the natural environment in the European Union, as amended by subsequent regulation No. 2006/21/EC. The main purpose of the legislation was to ensure that the polluter responsible for the damage pays all costs for rectifying its consequences. If it concerns damage to the natural environment, the operator must undertake measures for rehabilitation, replacement and regeneration of damaged natural resources. Primary replacement, which returns damaged natural resources to their original state, may be
\end{abstract}


differentiated from complementary replacement as compensation in the case in which primary replacement has not provided adequate reparation, and finally compensatory replacement compensation for temporary loss of natural conditions.

This paper is focused on an analysis of specific presumptions about the insurability of risk as concerns environmental insurance. Scientific paper aims at an analysis of the environmental insurance as a possible mean for eliminating risks due to liability for environmental impairment caused by the actions of an operator whose activities potentially threaten the natural environment and may cause biodiversity damage. There is the EU approach described, and the current demand required by the Directive is explored with respect to its impact on the Czech conditions. Risks are assessed with regard to risk insurability criteria for potential damage to the natural environment. The importance of risk management is stressed in the sophisticated form known as Enterprise Risk Management. Risk management is becoming increasingly important with consistent quantification of obvious, hidden and potential risks.

The paper was written as part of research project MSM 6215648904, carried out by the Faculty of Business and Economics, under the name "The Czech Republic in the processes of integration and globalization, and the development of the agriculture and service sector in the new conditions of the integrated European market", following the goals and methodology of the research project.

\section{Introduction}

In April 2004, the Environmental Liability Directive No. 2004/35/EC as amended by subsequent regulation No. 2006/21/EC was approved. The European insurance sector took an active part in transposing the Directive to the national legislative context of the European Union member countries. The basic principle of the Directive is the polluter-pays-principle. A polluter whose activities cause environmental damage or the direct threat of damage is financially liable for that damage. This liability is objective. Objective liability is liability for effects without regard to guilt or innocence, in contradistinction to subjective liability. The $\mathrm{CEA}^{1}$ welcomed the adoption of this Directive. At present, there is not developed environmental liability insurance market. The insurance industry is able to offer only a part of what the Directive requires for the costs of cleaning soil and water, with biodiversity damage ${ }^{2}$ very difficult to quantify reliably.

My paper is focused on an analysis of specific presumptions about the insurability of risk as concerns environmental insurance. This scientific paper aims at an analysis of the environmental insurance as a possible mean for eliminating risks due to liability for environmental impairment caused by the actions of an operator whose activities potentially threaten the natural environment and may cause biodiversity damage. I will describe the EU approach, primarily, and explore the current demand required by the Directive with respect to its impact on the Czech conditions. Risks are assessed with regard to risk insurability criteria for potential damage to the natural environment. The importance of risk management is stressed in the sophisticated form known as Enterprise Risk Management. Risk management is becoming increasingly important as part of the Solvency II concept, currently in

\footnotetext{
${ }^{1}$ CEA (Comité Européen des Assurances) - a federation of national insurers associations in 33 European countries

${ }^{2}$ Biodiversity damage is defined as the loss or weakening of an ecosystem functioning due to the weakening of some of its elements.
} 
preparation, whose first and second pillars accent risk management in financial institutions and consistent quantification of obvious, hidden and potential risks.

My methodological approach based on positive economic approach consists of standard scientific methods used, i.e. analysis, synthesis, description, comparison, deduction, induction, abstraction and concretization.

Environmental insurance began to appear in the developed countries at the end of the 1980's. In the European Union, it is available in every member country. The introduction of environmental insurance was one of the implicit conditions for the entry of the Czech Republic into the European Union. During the years 1999-2004, support for the development of environmental insurance was introduced as a priority task in the National Policy for the Natural Environment of the Czech Republic. Consequently, needs of protection of environment connected with risk prevention belong to key priorities for the program period of the European Union for the years 2007-2013.

Liability under Directive 2004/35/EC consists of two components: first, strict liability for specific risky activities defined in the IPPC (Integrated Pollution Prevention and Control) approval procedure, one of the conditions for obtaining permission to operate facilities. Second, liability linked to particular professional errors.

If the natural environment has not yet been damaged but is under real threat, the operator must take preventive measures determined beforehand without delay, according to GOODSTEIN (2008). If there is damage to the natural environment, the operator must take measures for its rehabilitation, replacement and the regeneration of damaged natural resources. Primary replacement, which returns damaged natural resources to their original state, may be differentiated from complementary replacement as compensation in a case in which primary replacement has not provided adequate reparation, and finally compensatory replacement - compensation for temporary loss of natural conditions (see JANATA, 2007).

CEA, the federation of national insurers association has published three reports in the last three years on the Environmental Liability Directive and the impact of its transposition into EU member state law. The first report "White Paper on Insurability of Environmental Liability" in January 2007 (see CEA, 2007) aimed to stimulate and deepen discussion ahead of the transposition deadline for the Environmental Liability Directive, while the second report "Enhancing Sustainable Insurance Solutions" in February 2008 (CEA, 2008) focused on the challenges posed by the transposition. It also highlighted areas that insurers may wish to consider when providing risk transfer solutions for the resulting liabilities.

The third report "Navigating the Environmental Liability Directive", April 2009, provides a deeper analysis of the findings and conclusions in last reports, based on most recent developments related to:

- the transposition of the Environmental Liability Directive,

- insurance matters linked to the transposition,

- the emergence of insurance solutions in some markets,

- risk selection and risk assessment,

- the development of new claims management skills,

- the cooperation with competent authorities (more in CEA, 2009). 


\section{Analysis of the environmental liability}

At the present time in the European Union, there exist, in terms of general liability, insurance products which partially cover some elements of the Directive, these being liability insurance for environmental damage occurring as a result of sudden, unexpected and uncontrollable accidents, for which damage compensation claims are based in civil law. As soon as the final extent of the legislation is known, the insurance industry will be able to begin preparing corresponding insurance products. One of the assumptions of risk insurability is legal clarity, comprehensibility, definiteness and a consistent legal environment. Only as part of such a legal framework can insurers precisely determine under what conditions they will be asked to reimburse damage claims and in what amount. European insurance companies use their experience and know-how from past environmental liability insurance activities to develop products which meet the Directive, including claims for damage reimbursement under public law and the coverage of new types of damage to the natural environment itself, so-called biodiversity damage, as well as costs for the prevention of this damage and its repair.

The evaluation of risk and its quantification in monetary terms is another of the assumptions of risk insurability. Among the fundamental presuppositions of insurability are randomicity and the willingness of at least one of several insurers on the market to offer a given type of insurance as a financial service, along with other criteria. Only incidents of damage which are random and whose risk may be quantified can be insured. It is a fundamental importance to the insurer that he has information about these events, their appearance, frequency, extent and seriousness in order to calculate premiums adequate to insure these risks. The most serious risks for insurance companies are unforeseeable claims for damage arising from changes in the legislative environment with retroactive effects or from developments in technology and knowledge (ZIKÁN, 2007).

If insurability in keeping with the demands of the Directive is to be achieved, insurers and reinsurers must be able to gain control over claims raised for compensation due to biodiversity damage, over the type of remediation and the course of remediation costs. Aside of insurers, of course, other potential providers of financial security must also be involved in the process of decision-making regarding the methods used to remedy biodiversity damage.

The Directive designates 3 levels of reparation for biodiversity damage:

1. primary - returning damaged natural resources or their worsened functioning to the basic conditions or towards that condition (baseline conditions)

2. complementary

3. compensatory

Compensatory reparation is highly problematic from an insurability standpoint, at present practically uninsurable, because at base it entails compensation for the interim loss of natural resources and functioning pending their renewal. This compensation comprises additional improvements to protected natural habitats and species or waters, either at the location of the damage or at a substitute locality. Its problematic nature lies in the fact that it involves improvements which go beyond the baseline conditions in the decisions of public administration bodies. The problem is that insurance companies do not have a primary objective of improving or capitalizing on the state of affairs after the occurrence of an insured event, but rather of compensating material damages, harm to health or lost utility. Compensatory reparation therefore entails a new type of compensation with which there is no 
experience and for which reliable statistical data is missing for all parties involved - public administration, operators and insurers.

Another critical point is cross-border biodiversity damage, where I consider a number of outstanding issues:

What responsibility regime is to be used for biodiversity damage which has already occurred?

Which authority will have responsibility for dealing with the damage?

Which body will decide about the choice of remedy for biodiversity damage?

What are the norms in neighbouring countries, or what are the required baseline conditions for damaged locations?

Answering these questions will be important for creating insurance products designed for multinational corporations which also have plants in other member countries of the European Union. For the Czech Republic, situated as it is on the watershed of Europe, this is of vital importance I have to emphasize.

European insurers now face the task, in close cooperation with the appropriate public authorities, of finding a method to quantify damage to the natural environment in monetary terms, as well as seeking ways and techniques by which biodiversity damage can be remedied, while respecting the rules for optimal effects by minimizing costs. A further consideration is that a selective market ${ }^{3}$ for a narrow circle of interested parties becomes a standard market in which all operators without regard to their size will have the possibility to select from insurance products which are capable of satisfying their individual needs at a price they find acceptable. To this end, insurers must learn how to calculate premiums in an amount such that premiums collected from all clients are sufficient to pay compensation for damage suffered by insureds, so that costs are covered and the insurance companies make a profit.

Therefore each insurer must be able to make a realistic and reliable estimate of potential damage over the longer term, must be able to determine the probability of damage and also foresee the scope and severity of damage in monetary terms. Insurers must learn new ways of evaluating risk from the standpoint of biodiversity damage. The risk underwriter must be able to distinguish between environmental risks for deciding about its acceptability for insurance and determining under what conditions it would be acceptable. The underwriter will require a number of details about the operator to be insured, such as the nature of the operations, the quantity and hazard posed by substances stored, the character of the surrounding of plants, possible means by which substances could escape from the operation and the history of past damage. Also important is an assessment of current pollution at the site and its environs, so that old ecological burdens may be separated from new and information may be acquired about baseline conditions.

Therefore, risk management aims to the fore of operators' interest, significantly more than in the case of other types of insurance. Insurance experts will evaluate external signals which as a rule indicate the quality of company management, since this guarantees a responsible approach to risk, as indicated in ZIKÁN (2007). Brokers need to educate clients on the increased potential requirements of the Environmental Liability Directive and then offer them some sort of protection, according to P̌̌EČKOVÁ (2009).

\footnotetext{
${ }^{3}$ A selective market may be labeled a ,niche“ market. In the case of environmental insurance, this needs to be changed into a „,mainstream“ market.
} 
Insurers will in my opinion especially require information about:

- the quality of the risk management system and the competence of the persons responsible for risk management,

- the accordance with all regulations, norms and laws,

- the risk assessment history and understanding of the special nature of environmental risks, together with plans for their minimization,

- introduction of a risk system like EMAS or ISO 14000,

- regular risk audits as well as the implementation of remedial measures when insufficiency is identified,

- financial stability of the organization - the enterprise must be profitable, otherwise in distress it might save on the risk management system and limit investment into safeguards and prevention of potential environmental damage,

- regular, systematic employee training,

- crisis plans and approaches, including the determination of detailed responsibilities for particular persons,

- adequate maintenance and testing of operational facilities as means of preventing potential environmental accidents.

The analysis of individual components of the overall risk management process is described in detail in a series of publications, e.g., VAUGHAN, VAUGHAN (2008). One of the key sources is described by PULCHART (2005). It is called the Risk Management Standard and is generally recognized as a basic guide for the risk management process. This basic process of corporate risk management is then - for example, in a financial institution - broken down into individual risk areas (where belong essentially market risk, credit risk, business risk and operational risk) with which the particular firm comes into contact. It may be illustrated using the following scheme:

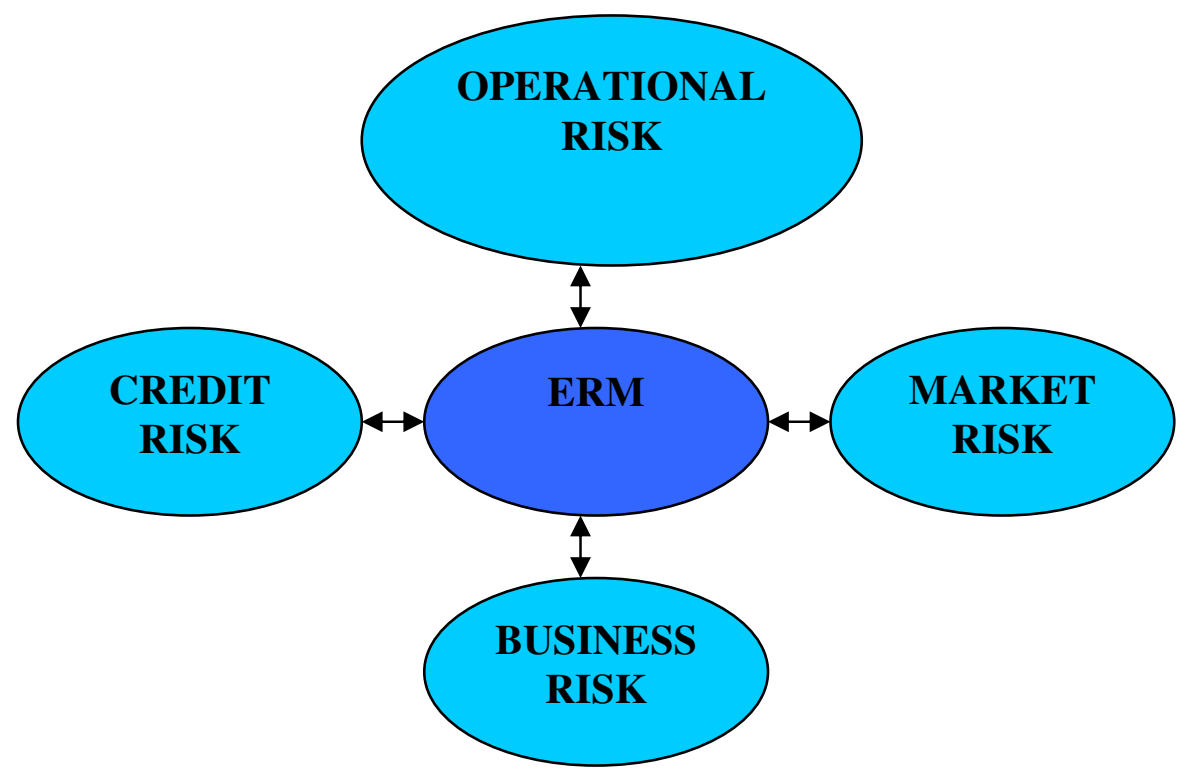

Scheme 1: Enterprise Risk Management scheme in a financial institution

A good risk management system aims at identifying and resolving risks. Its goal is to add maximum value to all the activities of the company. It provides documentation of the 
potential positive and negative effects of all factors which might influence the operator, increasing the probability of success and reducing the probability of failure and uncertainty in achieving company objectives. The concept of sophisticated risk management and its modelling comes to the fore. The risk management system functions with various levels of management, especially with the position of risk manager or CRO (Chief Risk Officer). Only in some cases however is there a system of risk management for a particular company which truly meets expectations and is part of the strategic decision making of senior management.

With that in mind, the risk management system should be integrated into the organization by means of effective principles and programs backed by senior management. It must be capable of converting strategies into tactical and operational goals and must define the tasks and duties of individual managers and staff responsible for risk management. A good risk management system supports responsibility, performance measurement and remuneration and thereby ensures action readiness at all levels. The result of introducing a system of quality financial controls and monitoring products offered, internal administrative processes and asset/liability management may then lead to a reduction in requirements for capital and to obtaining a competitive market advantage, building quality distribution and strengthening the good reputation of the firm.

The modelling of risk management is generally beneficial if done on the basis of sophisticated corporate risk management, i.e., ERM. First, it should be noted that risk management is an ongoing process, part of the management of the company and its strategy. Different authors present the structure of risk management in slightly different ways, but I consider the following elements of the process fundamental: 


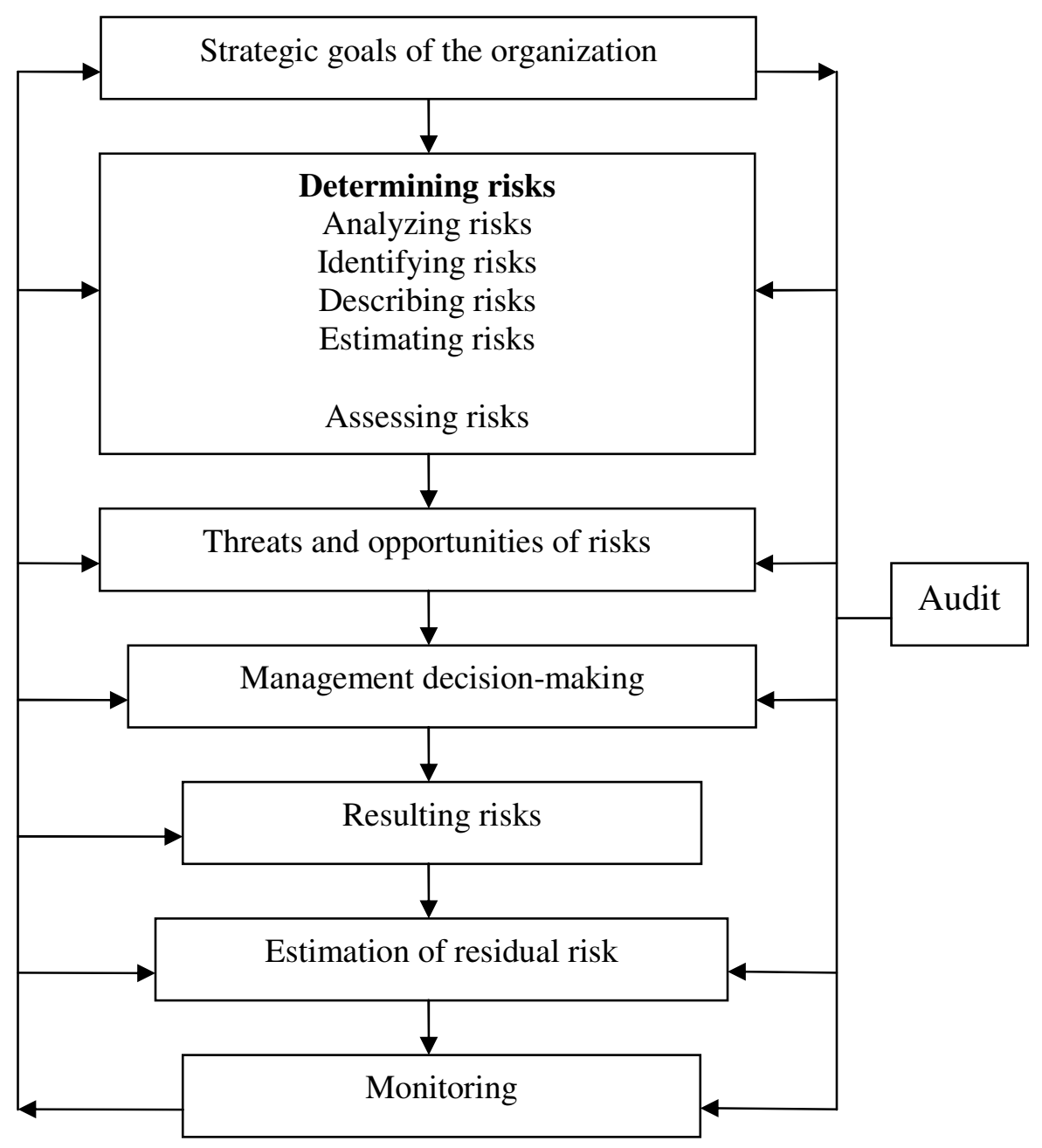

Scheme 2: Model of basic elements of the Enterprise Risk Management process Source: model on the basis of PULCHART (2005)

Enterprise risk management has gradually become a standard component of company management, and is an obligatory component of risk management, especially for large financial institutions. Risk management for insurers and reinsurers has been very well implemented but has lacked firm-wide coordination and interconnection. It has been aimed primarily at the process of minimizing the impact of the potential realization of risks and has lacked an integral component aimed at taking advantage of opportunities. Risk management in its sophisticated ERM form is becoming increasingly important in connection with the first and second pillars of the Solvency II concept, where there is a much stronger accent on a systematic and comprehensive approach to risk management (for more, see KAŠPAROVSKÁ, VÁVROVÁ, 2007).

New types of damage and cost compensation will mean finding new approaches and ways of managing loss adjustment, including acquiring experts (Claims Management). In accordance with GOODSTEIN (2008), I emphasize as especially necessary to: 
- develop best practices for dealing with insurance events in a way beneficial for the natural environment while at the same time eliminating nonessential costs,

- determine which existing techniques for repairing biodiversity damage are the most effective and optimal cost-wise,

- in the context of the above, to determine the price of these techniques, the number of organizations offering them with adequate experience and to judge whether these techniques are usable,

- allow insurance companies control over claims for environmental damage and reimbursement of costs for biodiversity damage reparations,

- discovering the functional relationship between insurance companies and administrative bodies in claims procedures,

- solve the problem of how to deal with damage reimbursement claims when the amount of damage exceeds the limit of the insurance.

The Directive allows member states to seek instruments for financial security in cases of insolvency of an operator. The European Commission has to provide until 30 April 2010, information about the accessibility and conditions for financial security and the possibility for operators to obtain such financial security (see CEA, 2009).

Liability for damage to the natural environment in the Czech Republic is governed by the provisions of the Civil Code (Art. 42 and et seq.). Significantly, liability for environmental damage is affected by Act No. 353/1999 Coll., on the prevention of major accidents, as amended by Act No. 59/2006 Coll., which contains a provision requiring obligatory insurance for damages caused to third parties, including environmental damage. Companies to which this Act applies are either Class A or Class B. By law they must draw up safety documentation in the form of a safety report for Class B and a safety study for Class A. Within a period of 100 days from the date of approval of this document by the relevant regional office, the operator must take out liability insurance for damage caused to a third party by any potential accident. The operator must present a copy of the documentation to the regional office within 30 days after concluding an insurance contract.

Reimbursement by the insurance company concerns only reimbursement for damages caused by major accidents. It also includes reasonable rescue costs for the limitation or prevention of damage or mitigation of its consequences. Insurance excludes the risk of war and exposure to ionizing radiation, as with other insurance liabilities. Biodiversity damage is excluded ${ }^{4}$ because it cannot be quantified and is therefore very difficult for the insurer to compensate, as the quantification of potential damage is a fundamental condition for the insurability of risk. Excluded is damage directly due to poor technical condition or neglected maintenance. Also not covered by the insurance is damage which has occurred due to the gradual, long-term effects of hazardous substances ${ }^{5}$. Insurance applies only to sudden, unexpected damage as in, e.g., the rupture of vessels or pipes, an explosion or fire.

In the Czech Republic, the government proposal for the Act dealing with the prevention of biodiversity damage and its reparation and on changes in other legislation, contains in the appropriate $\S 14$ postponements concerning obligatory financial security by 1 January 2013 , i.e., only after the planned assessment of accessibility of appropriate financial security by the European Commission (in CEA, 2009). This Act was approved under the No. 167/2008 Coll.,

\footnotetext{
${ }^{4}$ Biodiversity damage is defined in $\S 10$ of Act No. 17/1992 Coll., on the natural environment.

${ }^{5}$ So-called "gradual pollution".
} 
on the prevention of biodiversity damage and its reparation, in force since 17 August 2008. Operators are under obligation to assure the financial security for covering costs for reparation of biodiversity damage, following this Act. The Czech government provides for regulation of the way of assessment of risks, criteria for consideration of sufficient financial provision and detailed conditions for financial security for measures for prevention and reparation.

\section{Conclusions}

An analysis of the legislative situation before the introduction of Environmental Liability Directive No. 2004/35/EC leads me to the following conclusions:

In many areas, environmental issues are already adequately regulated. These include protection of the soil, old environmental burdens and their liquidation, water resources, the protection of nature, waste management, managing hazardous substances, clean air, genetically modified organisms, agriculture and forestry, fisheries and regional planning. New European legislation is substantially stricter than past approaches, in my opinion. It enables member countries to introduce more strict criteria exceeding minimum standards. Implementation in national legislation will mean meshing existing laws together with a panEuropean approach.

Prudent operators and their risk managers will seek opportunities for optional insurance as soon as possible, to limit financial consequences of a potential environmental accident on their business. Finally, their liability for biodiversity damage and obligation to reimburse costs for the prevention of damage and to remedy biodiversity damage will become effective immediately upon passage of the Act.

The presentation of offers for insurance products which will be compatible with the requirements of the Directive will take some time. Because of competition in the European insurance market, it may be anticipated that insurers in individual European countries, in close cooperation with the reinsurance market, will adapt to this challenge depending upon the extent and legal framework the relevant public authorities will use to implement the provisions of the Directive into national legislation. In my opinion, the free-market process of decision-making should be without the introduction of obligatory financial security.

\section{Literatura:}

[1] CEA: Navigating the Environmental Liability Directive, April 2009. [online] Dostupné na: <http://www.cea.eu/uploads/DocumentsLibrary/documents/1240585425_eld-bestpractice-guide-update.pdf>

[2] CEA: The Environmental Liability Directive: Enhancing Sustainable Insurance Solutions, February 2008. [online] Dostupné na: <http://www.cea.eu/uploads/DocumentsLibrary/documents/1203085136_environmental -liability report.pdf>

[3] CEA: White Paper on Insurability of Environmental Liability, January 2007. [online] Dostupné na: <http://www.cea.eu/uploads/DocumentsLibrary/documents/Mail\%20\%20CEA\%20White\%20Paper\%20on\%20Insurability\%20of\%20Environmental\%20Lia bility.pdf>

[4] GOODSTEIN, E. S. Economics and the Environment. USA: Wiley, 2008. 512 s. ISBN 978-0-471-76309-3.

[5] JANATA, J. Pojištění škod na životním prostředí v EU. In Pojistný obzor, LXXXIV, 10, Praha: ČAP, 2007. ISSN 0032-2393. 
[6] KAŠPAROVSKÁ, V., VÁVROVÁ, E. Dopady regulace finančních institucí v novém prostředí. In Sborník z mezinárodní vědecké konference Firma a konkurenční prostředí 2007, Brno: MSD, 2007. ISBN 978-80-86633-85-5.

[7] P̌̌EČKOVÁ, L. Pojištovací zprostredkovatelé na pojistném trhu v České a Slovenské republice. In Acta academica karviniensia, X, 1, Karviná: OPF SLU, 2009. ISSN 1212$415 X$.

[8] PULCHART, V. Kapitál a risk management v pojištovně. In Pojistný obzor, LXXXII, 10, Praha: ČAP, 2005. ISSN 0032-2393.

[9] VAUGHAN, E. J., VAUGHAN, T. Fundamentals of Risk and Insurance. Iowa: Wiley, 2008. 643 s. ISBN 978-0-470-08753-4.

[10] ZIKÁN, V. Bílá kniha CEA o pojistitelnosti odpovédnosti za škodu na životním prostředí. In Pojistné rozpravy, 21, Praha: ČAP, 2007. ISSN 0862-6162.

[11] Zákon č. 167/2008 Sb., o předcházení ekologické újmě a o její nápravě a o změně některých zákonů.

[12] Zákon č. 353/1999 Sb., o prevenci závažných havárií, ve znění novely č. 59/2006 Sb.

\section{JEL classification: G15, G22, Q5}

\section{Ing. Eva Vávrová, Ph.D.}

odborný asistent Ústavu financí

Fakulta provozně ekonomická

Mendelova univerzita v Brně

Zemědělská 1, 61300 Brno

vavrova@mendelu.cz 